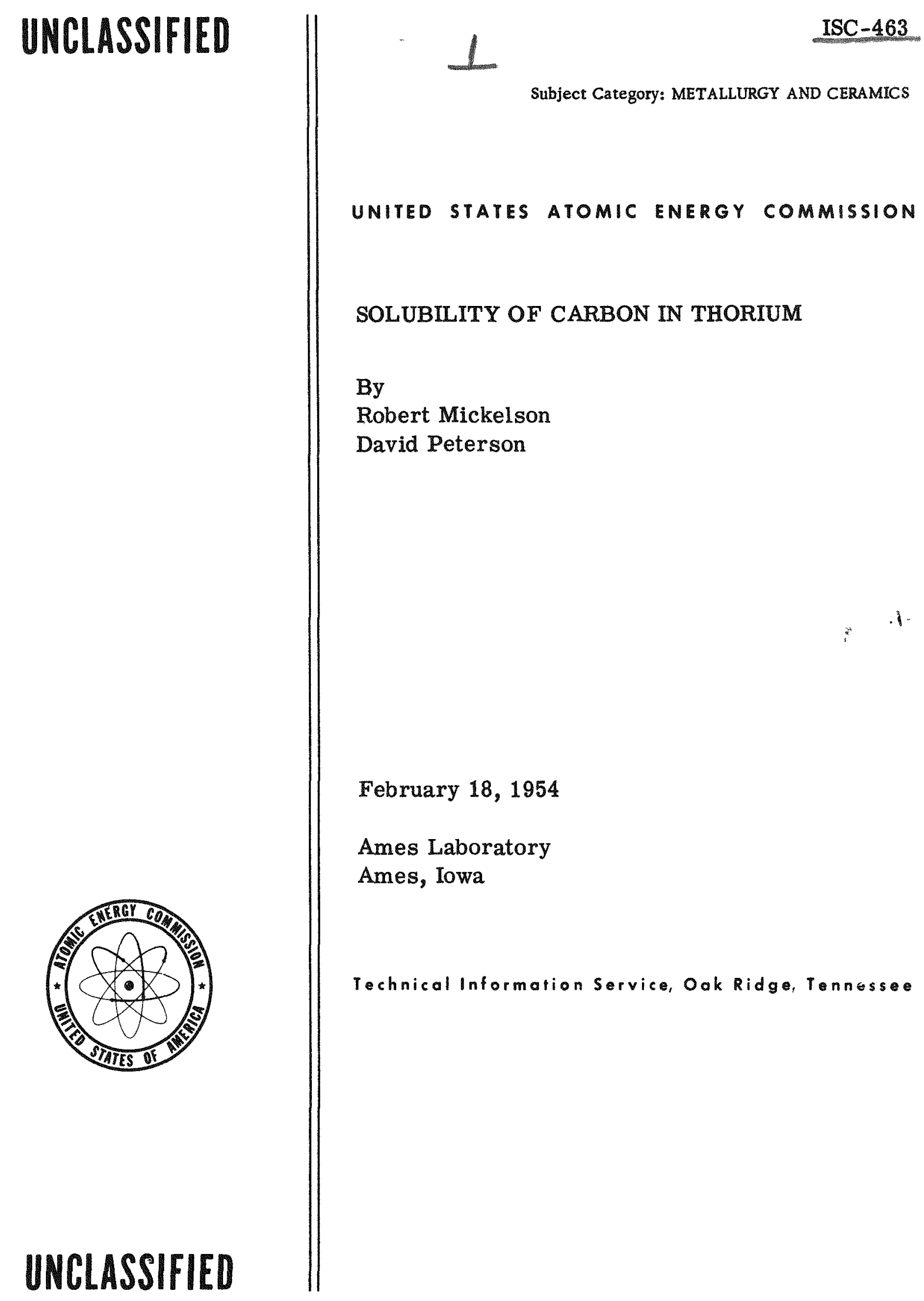




\section{DISCLAIMER}

This report was prepared as an account of work sponsored by an agency of the United States Government. Neither the United States Government nor any agency Thereof, nor any of their employees, makes any warranty, express or implied, or assumes any legal liability or responsibility for the accuracy, completeness, or usefulness of any information, apparatus, product, or process disclosed, or represents that its use would not infringe privately owned rights. Reference herein to any specific commercial product, process, or service by trade name, trademark, manufacturer, or otherwise does not necessarily constitute or imply its endorsement, recommendation, or favoring by the United States Government or any agency thereof. The views and opinions of authors expressed herein do not necessarily state or reflect those of the United States Government or any agency thereof. 


\section{DISCLAIMER}

Portions of this document may be illegible in electronic image products. Images are produced from the best available original document. 
Date Declassified: September 8, 1955.

This repont was prepared as a scientific account of Government-sponsored work and is made available without review or examination by the Government. Neither the United States, nor the Commission, nor any person acting on behalf of the Commission makes any warranty or representation, express or implied, with respect to the accuracy, completeness, or usefulness of the information contained in this report, or that the use of any information, apparatus, method, or process disclosed in this report may not infringe privately owned rights. The Commission assumes no liability with respect to the use of, or for damages resulting with respect to the use of any information, apparatus, method, or process disclosed in this report.

This report has been reproduced directly from the best available copy.

Issuance of this document does not constitute authority for declassification of classified material of the same or similar content and title by the same authors.

Printed in USA, Price 20 cents. Available from the Office of Technical Services, Department of Commerce, Washington $25, \mathrm{D}$. C. 


\title{
SOLUBILITY OF CARBON IN THORIUM
}

\author{
$\mathrm{By}$
}

Robert Mickelson and David Peterson

February 18, 1954

Ames Laboratory

at

Iowa State College

F. H. Spedding, Director

Contract $w-7405$ eng-82 
.

.

.

.

. 


\title{
SOLUBILITY OF CARBON IN THORIUM
}

\author{
By \\ Robert Mickelson and David Peterson
}

\begin{abstract}
The solubility of carbon in thorlum has been investigated and the limit of solubility has been determined at four temperatures. Thorlum-carbon samples, containing from 0.025 to 1.23 weight per cent carbon, were prepared by arc melting sponge thorlum with high purity graphite. $\mathrm{X}$-ray data, hardness readings, and metallographic examinations of heat treated specimens were combined to obtain the following solubility limits: room temperature - $0.35 \%$ carbon, $800^{\circ} \mathrm{C}-0.43 \%^{\circ}$ carbon, $1018^{\circ} \mathrm{C}-0.57 \%$ carbon, and $1215^{\circ} \mathrm{C}-0.91 \%$ carbon.
\end{abstract}

\section{INTRODUCTION}

Carbon has been found to be the most effective alloying element In changing and Improving the mechanical properties of thorium meta1. Petersonl reports that additions of carbon to thorium increase the hardness and tensile strength without seriously reducing ductility. The investigation of the solubility of carbon in thorium was undertaken to provide basic information of value in understanding the effect of carbon on the physical properties of thordum.

The thorlum-carbon system has been 1nvest1gated by Ch1ott1, who reports that thorium monocarbide is the stable phase in equilibrium with thorium at room temperature. Thorium and thorium monocarbide are reported to be completely soluble in the liquid and solid states at elevated temperatures. The exact limits of the solubility of carbon in thorium were not extensively investigated. Saller 3 investigated the solubility of carbon in thorlum and found considerable variation between the results of X-ray diffraction and metallographic examination. His conclusion was that the metallographic results were more accurate. 
ISC -463

II. EXPERIMENTAL

A. Preparation of Samples.

The thorium-carbon samples used in this investigation were prepared by arc melting in a water-cooled copper crucible. The crucible was evacuated to less than 0.1 micron and fllied with purifled helium. A plece of zirconium metal was then melted to remove any oxygen or nitrogen still present in the furnace. The samples, which welghed about 100 grams, were prepared by melting Ames sponge thorium and dissolving high purity graphite in the molten metal. Each sample was turned and remelted three times to insure homogene1ty.

The thorium sponge and the thorfum-carbon samples were chem1cally analyzed for carbon and nitrogen. The thorium sponge contained 0.026 weight per cent carbon and 0.026 weight per cent nitrogen. The average nitrogen content of the seventeen samples was 0.032 weight per cent. The thorium sponge and five thoriumcarbon samples were spectrographically analyzed for eleven different impurities.

\section{B. Heat Treatment.}

Samples used to determine the room temperature solubility IImit were heated in a quartz tube evacuated to less than 0.02 micron. The samples were held at $900^{\circ} \mathrm{C}$ for $\mathrm{six}$ hours and cooled to room temperature over a period of five days.

A molybdenum tube resistance furnace was adapted to quench samples into molten Wood's metal placed on the furnace base directly beneath the cylindrical heater. The heating was done under a vacuum of 0.4 micron or lower. The samples were supported on a thorlum disk which was allowed to fall into the quenching vessel with the samples. Since heating and quenching were done under vacuum and the samples were in contact only with thorium, the chances for contamination of the samples were reduced. The samples were held at temperature for 30 minutes or more before quenching. The Wood's metal was malntalned at $80-100^{\circ} \mathrm{C}$.

C. X-ray Study.

Lattice parameter determinations were made on a North American Phililps back-reflection camera which has a diameter of $12 \mathrm{~cm}$. Samples containing less than 0.1 welght per cent carbon were hotrolled to $1 / 16$ inch sheet and shaped to the circumference of the camera before undergoing heat treatment. Samples containing more than 0.1 per cent carbon were too brittle to roll and blocks $1 / 16$ inch thick and $1 / 4$ inch wide were used in the $X$-ray camera. In 
every instance, before the sample was exposed it was vigorously pickled in dilute nitric acid which contained a small amount of hydrofluoric acid. This pickling was performed to remove the surface metal which might have become contaminated during heat treatment.

Thorlum oxide lines appeared on most of the X-ray photographs. These lines were more sharply defined than the thorium lines and, consequently, they could be measured with greater accuracy. Thus, thorlum oxide was used as an internal standard to eliminate systematic errors in the determination of the lattice constant. If the thorium oxide lines indicated that there was an appreciable error in a given film, this error was eliminated by a graphical extrapolation against $\sin ^{2} \theta$.

The samples of thorium containing more than 0.5 per cent carbon were very coarse-grained, particularly when quenched from the higher temperatures. As a result, the $\mathrm{X}$-ray diffraction patterns were very spotty and the accuracy of f1lm measurement was poor. Since massive samples were used, there was no way of eliminating this difficulty.

A maximum probable error in the measurement of the lattice constant was calculated from a reasonable assumed error in measuring the flim. A larger assumed error was used for samples containing more than 0.5 per cent carbon because of the spotty lines from these samples. The systematic error in many of the determinations was less than this maximum probable error and, in these cases, no correction was made.

D. Metallographic Examination.

The samples for metallographic examination were ground on $320,400,500$, and 600 grit paper. They were polished with Iinde $B$ on Microcloth. Etching was used to improve the contrast between thorium monocarbide and thorlum. The presence of thorlum carbide could usually be detected before etching, but the improved contrast made the pictures clearer. The etching solution was 2 molar nitric ac1d, 0.02 molar hydrofluoric actd, and 0.005 molar thorium nitrate. The etching solution was applied by swabbing for ten to thirty seconds.

\section{RESULTS AND DISCUSSION}

The spectroscoplc analyses of the thorium metal used in preparing the samples and of a number of the samples are given in Table I. Most of these results are an upper limit since the 
actual content was below the limit of measurement of the methods used. The principal difference in purity between these samples and Ames production thorium metal was in the beryllium content. These samples contain less than $20 \mathrm{ppm}$ beryllium while Ames thorium, due to being melted in beryllia, usually contains 100 ppm or more.

The chemical analyses of the thorlum-carbon samples for nitrogen and carbon are presented in Table II. The oxygen content of these samples was not determined but must have been above the solubility limit since thorium oxide was observed in the microstructures of all these samples. The thorium oxide content was probably between one and two per cent. In graphing the results of this investigation, the error in the carbon analysis was assumed to be five per cent of the absolute value of the carbon content.

Table I

Spectroscoplc Analysis of Thorlum-Carbon Samples

\begin{tabular}{|c|c|c|c|c|c|c|c|c|c|c|c|}
\hline \multirow{2}{*}{$\begin{array}{l}\text { Sample } \\
\text { Number }\end{array}$} & \multicolumn{11}{|c|}{ Impur1ty Content ppm } \\
\hline & $\overline{\mathrm{Be}}$ & AI & $\overline{\mathrm{Ca}}$ & $\mathrm{Mg}$ & Si & Fe & Mn & $B$ & cd & $\overline{\mathrm{Zn}}$ & $2 r$ \\
\hline Sponge & $<20$ & $<25$ & $<50$ & $<20$ & $<50$ & 40 & $<20$ & 0.75 & $<0.2$ & 110 & $<100$ \\
\hline 1 & $<20$ & $<25$ & $<50$ & $<50$ & $<50$ & 35 & $<20$ & $<0.3$ & 0.3 & $<10$ & $<100$ \\
\hline 2 & $<20$ & $<25$ & $<50$ & $<50$ & $<50$ & 30 & $<20$ & $<0.3$ & $<0.2$ & $<10$ & $<100$ \\
\hline 3 & $<20$ & $<25$ & $<50$ & $<20$ & $<50$ & 105 & $<20$ & 0.45 & 2.1 & 12 & $<100$ \\
\hline 5 & 20 & $<25$ & $<50$ & $<20$ & $<50$ & 35 & $<20$ & $<0.3$ & 0.3 & $<10$ & $<100$ \\
\hline 6 & $<20$ & $<25$ & $<50$ & $<20$ & $<50$ & 45 & $<20$ & $<0.3$ & $<0.2$ & $<10$ & $<100$ \\
\hline
\end{tabular}

The solid solubility limits of carbon in thorium were established from the $\mathrm{X}$-ray data and confirmed by microscopic examination. The observed lattice constants of the samples after various heat treatments are reported in Table III and are plotted in Figure 1 agalnst the carbon content. The solubility limit at each temperature was taken as the carbon content above which there was no further increase in lattice constant. The experimental error is indicated by horlzontal and vertical lines through each point.

The solid solubility limits of carbon in thorium are shown in Figure 2 as a function of temperature. 
Table II

Analysis and Hardness of Thorlum-Carbon Samples

Rockwell A Hardness

Sample Nitrogen Carbon Content Heated Quenched Quenched Quenched Number Content, Welght Atomic at ${ }^{\circ}$ from from from $\mathrm{ppm}$ Per Cent per cent $900^{\circ} \mathrm{C} \quad 800^{\circ} \mathrm{C} \quad 1018^{\circ} \mathrm{C} \quad 1215^{\circ} \mathrm{C}$ cooled

\begin{tabular}{|c|c|c|c|c|c|c|c|}
\hline 1 & 471 & 0.025 & 0.47 & 23 & - & 24 & 25 \\
\hline 2 & 344 & 0.054 & 1.03 & - & 27 & 29.5 & - \\
\hline 3 & 344 & 0.026 & 0.49 & 26 & - & - & 28 \\
\hline 4 & 203 & 0.035 & 0.67 & - & - & - & - \\
\hline 5 & 482 & 0.042 & 0.81 & - & - & 29 & - \\
\hline 6 & 241 & 0.104 & 1.98 & - & 38 & 36 & - \\
\hline 7 & 301 & 0.132 & 2.49 & - & - & - & 43.5 \\
\hline 8 & 1,015 & 0.163 & 3.06 & 38 & 44 & 48.5 & 50 \\
\hline 9 & 332 & 0.208 & 3.87 & 41.5 & - & 48.5 & - \\
\hline 10 & 293 & 0.239 & 4.44 & 44 & - & 52 & 54 \\
\hline 11 & 253 & 0.300 & 5.50 & 46 & 49 & $5 I$ & - \\
\hline 12 & 224 & 0.350 & 6.36 & 50 & 54 & 55.5 & - \\
\hline 13 & 143 & 0.408 & 7.37 & - & - & 50 & - \\
\hline 14 & 215 & 0.556 & 9.82 & 53 & - & 62.5 & - \\
\hline 15 & 178 & 0.736 & 12.59 & 55 & 58.5 & 64 & - \\
\hline 16 & 168 & 0.959 & 15.78 & 57.5 & 60 & 64 & - \\
\hline 17 & 182 & 1.228 & 19.40 & - & - & 66.5 & - \\
\hline
\end{tabular}


Table III

Lattice Constants of Thorium-Carbon Samples

\begin{tabular}{cccccc}
\hline $\begin{array}{c}\text { Sample } \\
\text { Number }\end{array}$ & $\begin{array}{c}\text { Carbon } \\
\text { Content, } \\
\text { Weight } \\
\text { Per Cent }\end{array}$ & $\begin{array}{c}\text { Heated at } \\
900^{\circ} \mathrm{C} \text { and } \\
\text { Slow-Cooled }\end{array}$ & $\begin{array}{c}\text { Quenched } \\
\text { from } \\
800^{\circ} \mathrm{C}\end{array}$ & $\begin{array}{c}\text { Quenched } \\
\text { from } \\
1018^{\circ} \mathrm{C}\end{array}$ & $\begin{array}{c}\text { Quenched } \\
\text { from } \\
1215^{\circ} \mathrm{C}\end{array}$ \\
\hline 1 & 0.025 & 5.0871 & 5.0877 & 5.0920 & 5.0900 \\
2 & 0.054 & 5.0886 & 5.0922 & - & - \\
3 & 0.026 & 5.0871 & 5.0875 & - & 5.0867 \\
4 & 0.035 & 5.0873 & 5.0926 & 5.0905 & - \\
5 & 0.042 & 5.0859 & - & - & - \\
6 & 0.104 & 5.0953 & 5.0958 & - & - \\
7 & 0.132 & 5.0964 & - & 5.1064 & 5.1075 \\
8 & 0.163 & 5.0966 & 5.1033 & - & 5.1107 \\
9 & 0.208 & 5.1004 & - & - & - \\
10 & 0.239 & 5.1020 & - & 5.1203 & 5.1183 \\
11 & 0.300 & 5.1058 & 5.1140 & 5.1196 & - \\
12 & 0.350 & 5.1077 & 5.1211 & 5.1272 & 5.1216 \\
13 & 0.408 & 5.1077 & 5.1305 & 5.1356 & 5.1325 \\
14 & 0.556 & 5.1092 & 5.1270 & 5.1380 & 5.1433 \\
15 & 0.736 & - & 5.1250 & 5.1425 & 5.1532 \\
16 & 0.959 & 5.1077 & 5.1243 & 5.1447 & 5.1613 \\
17 & 1.228 & - & - & 5.1436 & 5.1573 \\
\hline
\end{tabular}




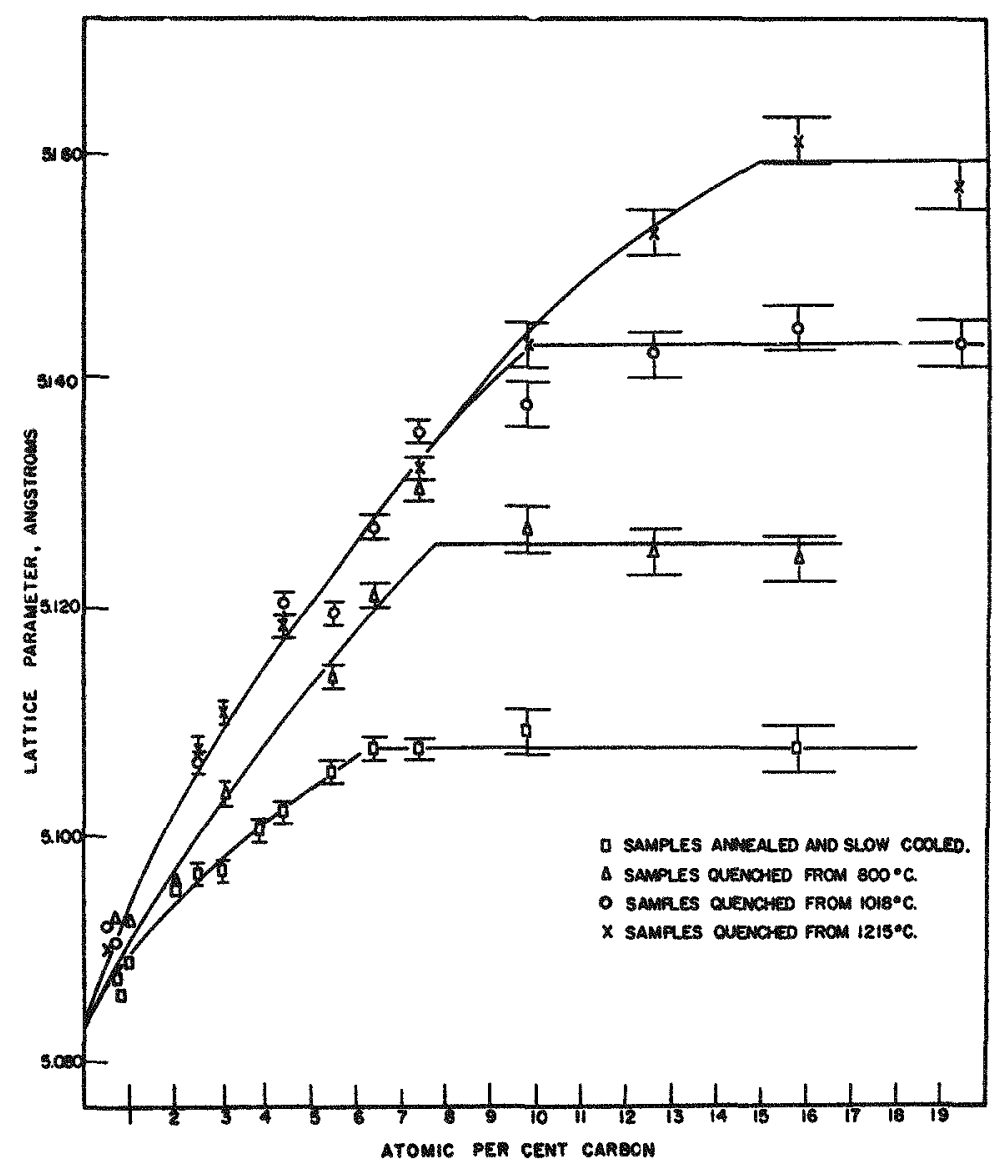

F1g. 1 Lattice Constants of Thorium-Carbon Samples with Various Heat Treatments. 


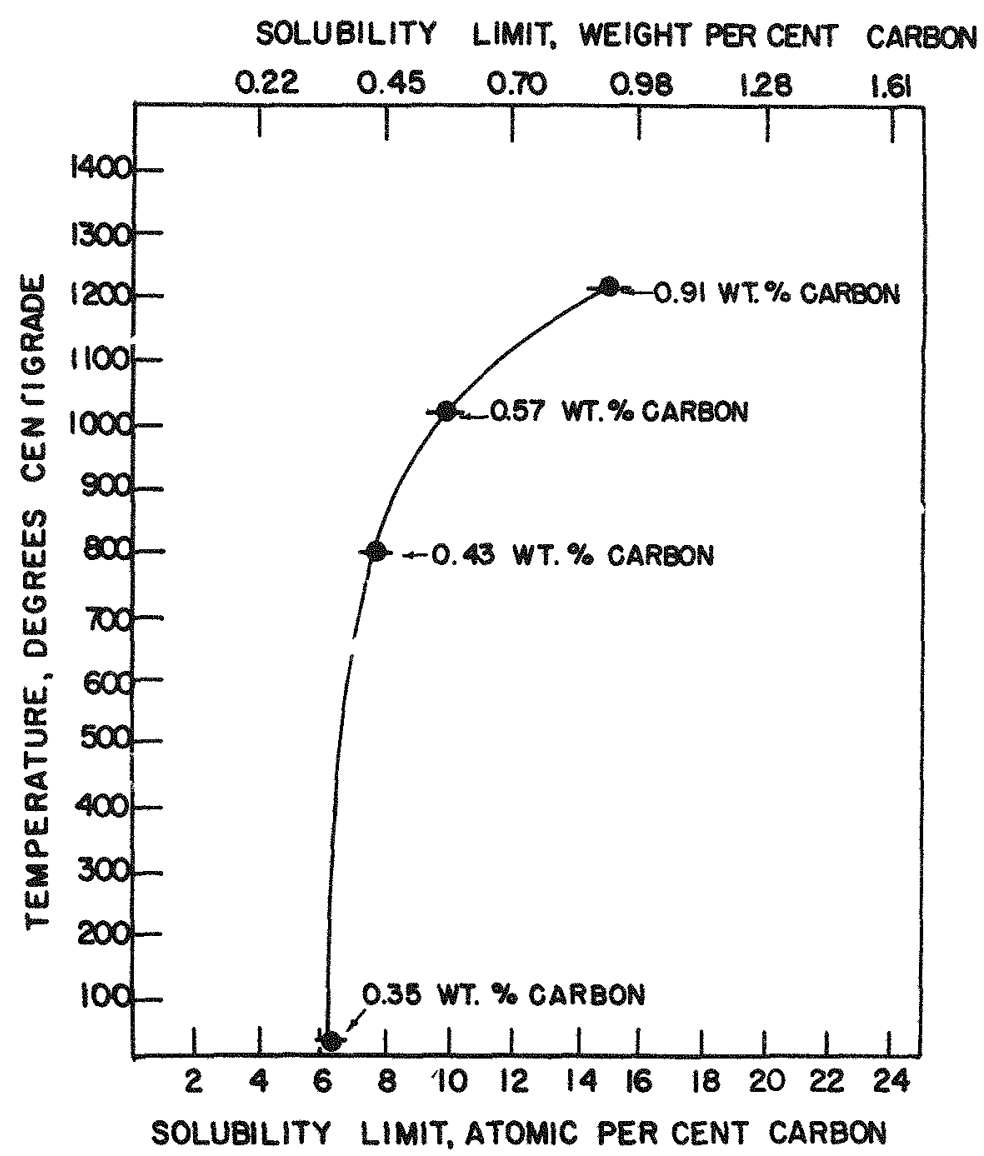

Fig. 2 Solubility of Carbon in Thorium of Various Temperatures. 
The solubility limits established by $X$-ray methods were checked by microscopic examination. Thorium carbide could be identified as small particles which tend toward a square form. The thorium oxide particles were much larger and darker in color.

Figures 3 and 4 show samples above and below the solubility IImit at each temperature. These pictures show the precipitation of thorium carbide in samples above the solubility limits.

An anomalous effect was observed in samples which contalned less than 0.35 per cent carbon and hence were not saturated with carbon. These quenched samples showed an increase in lattice constant over the slow-cooled samples of the same carbon content, and, up to $1000^{\circ} \mathrm{C}$, the higher quenching temperatures resulted in an increased lattice constant. A similar effect was observed in the increased hardness of unsaturated samples quenched from various temperatures. The most likely explanation is that the samples were saturated with nitrogen at room temperature and heating to higher temperatures caused more thorium nitride to dissolve in the thorium. Thorium nitride has been reported by Chiottie to be appreciably soluble in thorlum at elevated temperatues.

\section{CONCLUSIONS}

The solubility of carbon in thorium was established as 0.35 per cent at room temperature, 0.43 per cent at $800^{\circ} \mathrm{C}, 0.57$ per cent at $1018^{\circ} \mathrm{C}$, and 0.91 per cent at $1215^{\circ} \mathrm{C}$. Increasing the carbon content causes an increase in the hardness of thorlum by solid solution hardening. An impurity in these samples, believed to be nitrogen, caused an increased lattice constant and hardness of quenched alloys below the carbon solubility limit.

\section{LITERATURE CITED}

1. Peterson, D. and R. F. Russ1, "The Effect of Minor Add1t1ons on the Mechanical Properties of Ames Thorlum," Proceedings of the Spring Metallurgy Conference, 1952, TID-5084, p. 459-71, (1952).

2. Chiotti, P., "Thorium-Carbon System," AECD-3072, (1950).

3. Grenell, I. H. and H. A. Saller, "The Solubility of Carbon in Thorlum," CT-3411, (1946). 


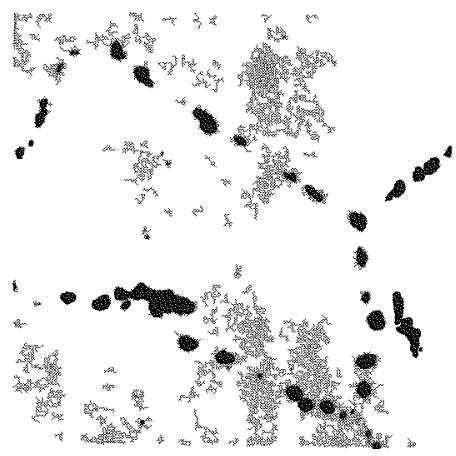

A
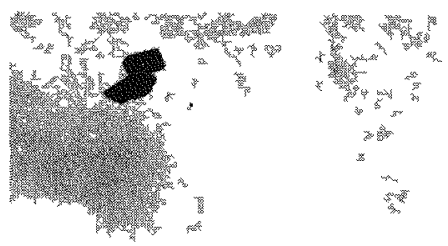

C

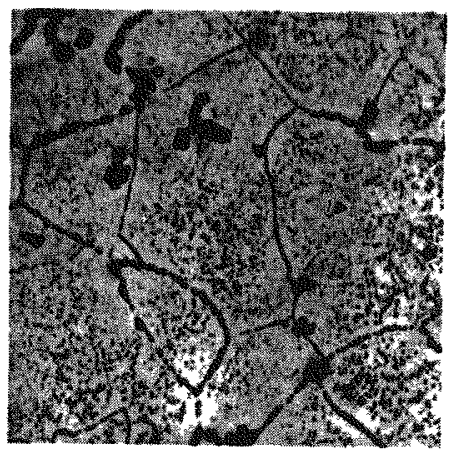

$B$

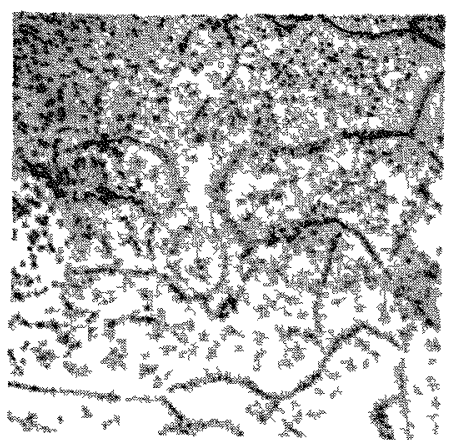

D

Fig. 3 Thorium-Carbon Samples. Nitric Acid Etch. X500. A - 0.30\% Carbon. Slow-Cooled. B - 0.408\% Carbon. Slow-Cooled. $\mathrm{C}-0.350 \%$ Carbon Quenched from $800^{\circ} \mathrm{C}$. $\mathrm{D}-0.736 \%$ Carbon. Quenched from $800^{\circ} \mathrm{C}$. 


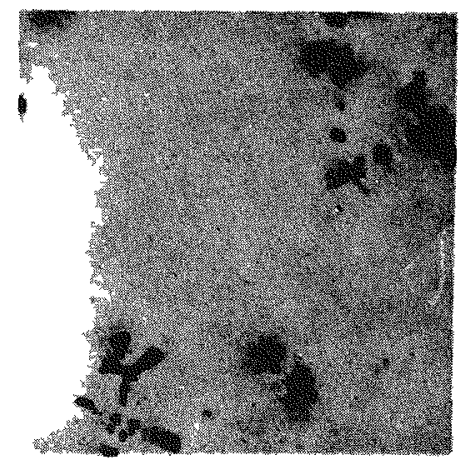

A

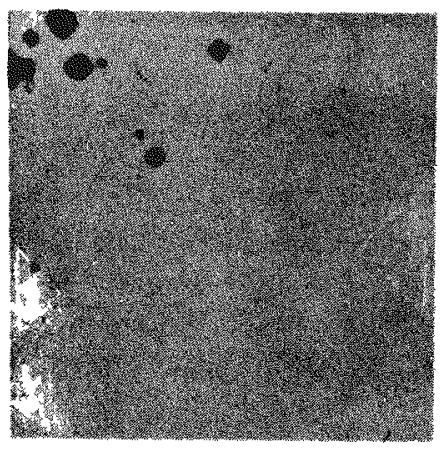

$\mathrm{C}$

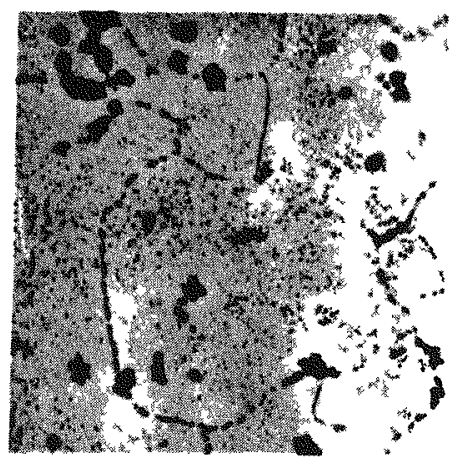

B

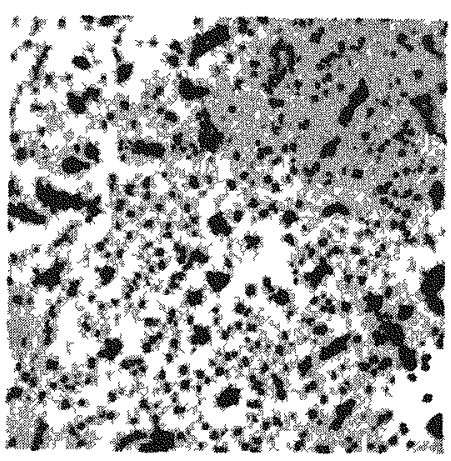

D

Fig. 4 Thorium-Carbon Samples. Nitric Acid Etch. X500. A - $0.408 \%$ Carbon. Quenched from $1018^{\circ} \mathrm{C}$. B - $0.736 \%$ Carbon. Quenched from $1018^{\circ} \mathrm{C}$ C $-0.736 \%$ Carbon. Quenched from $1215^{\circ} \mathrm{C}, \mathrm{D}-0.959 \%$ Carbon. Quenched from $1215^{\circ} \mathrm{C}$. 